\title{
INFLUENCE OF CHANGES IN TRANSACTION COSTS ON THE TRANSFORMATIONS OF ENTERPRISES
}

\author{
Władysław Szymański*
}

\begin{abstract}
Background. The article analyses the possibility of creating additional economic benefits as a result of enterprises effective adaptations to the changes of transaction costs.

Research aims. The article answers the question: whether it is useful and justified to separate and transfer certain activities abroad, and what form could be appropriate to this.

Methodology. The author presents the main assumptions and benefits of the network approach to companies' cooperation, as well as a concept of business network and strategic network of companies.

Findings. The Author presents the possibility of creating enterprises' flexible adaptation to the transaction cost changes. In the article he suggests creating incubators of the intelligent firms.
\end{abstract}

Key words: changes, transaction cost, enterprise, commission, profit, flexible.

JEL Codes: A100, F000, G000

\section{INTRODUCTION}

In recent decades the transformations of enterprises have been to a large extent a derivative of changes in transaction costs in the formula of the Nobel Prize winner of 1991, Ronald Coase, often referred to as the father of entrepreneurship. Ronald Coase recognized the necessity of analyzing the costs of analogous activities within the company in comparison with the costs of their purchase or orders, which he defined 
as transaction costs (Coase, 1937). In 1937 Coase was of the opinion that the situations in which the costs of the organization of operations in the enterprise are lower than transactions on the market prevail. Thus, there is a tendency to concentrate and increasingly develop individual departments and organizational units. For decades, it was recognized that internalization of market transactions within the company's organizational structures is progressing. In the early 1990s, the Nobel Prize winner Oliver Williamson (Williamson, 1998, p. 391) claimed that own resource operations are more profitable, as the transaction costs associated with the need to continuously supervise external suppliers and service providers are often higher than the savings achieved thanks to their greater work efficiency.

Currently, even a cursory observation of economic reality makes us aware of the change in the tendency, i.e. the transition from internalization to externalization, that is, more and more activities from enterprises are transferred outside. More and more widely, market transactions and orders are contracted to other entities. This shows that the relationship between the price of orders on the market, and hence the transaction costs, and the costs of analogical activities in the enterprise, which are increasingly higher, changes.

In recent decades, many factors have arisen that have influenced the change of relations in favor of orders. First of all, the IT revolution and the Internet have overturned the barrier of time and space, and thus enabled real-time communication with the whole world, and this is the way to get to learn about the market, which determines the possibility of using profitable orders. At the same time, the globalization process, opening the market, reveals huge differences in costs, taxes, exchange rates and wages. The use of differences, and so-called commercial arbitrage, is nothing more than the use of profitable orders, i.e. lower transaction costs than the costs of operations in an enterprise. The Internet, teleworking, the progress of digitization mean a rapid development of cyber-migration, and thus providing services electronically requiring high qualifications, and much cheaper. Currently, most American consumer telephone service offices are located in the Indian Silicon Valley in the state of Bangalore. American tax advisors and accountants are increasingly commissioning Indian subcontractors to calculate their clients' taxes. The progress in transport and the development of containerization has had a major impact on the development of orders and the use of 
global market subcontractors. It caused not only a reduction of costs, but also protection against damage, which allowed safe transport of processed and more complex products. At the beginning of the 20th century, unprocessed products prevailed in import and export, and currently $80 \%$ of processed goods are found in US exports. Adequate progress is being made as a result of digitization in logistics, which determines the quality of deliveries precisely on time.

The above factors show new possibilities of using transaction costs, and thus the use of sub-suppliers and cooperators. But there is also another side, there are not only more and more opportunities, but the need to analyze transaction costs increased at the same time. The intensity of competition has increased, so the compulsion to care for costs and quality increases. The use of alternative costs and transaction costs of the global market determines this condition.

\section{Concentration and character of the enterprise in the situation of changes in transaction costs}

At the beginning Ronald Coase posed a significant question: Why do islands of conscious management (and therefore "commandship") occur in the ocean of the market? For this, it was necessary to distinguish the costs of the market mechanism from the costs of similar activities, that is creating the same element of production of goods and services, in the enterprise. In this way, Coase could determine the basis for the size and growth of the company.

Analyzing the transaction costs of the market, it was possible to answer the above question. It will increase its size until the costs of its operation are equal to the transaction costs of the market (Coase, 1937, p. 395). Simplifying, the enterprise will develop additional departments and organizational units, as long as their costs are lower than the costs of orders and purchase of similar activities outside.

The above Coase approach means a change in the approach to the factors determining the size of the enterprise. Both earlier and today, textbooks are dominated by the conviction that the technological factors are a decisive factor. According to Coase the structure of the market, mostly the structure of potential sub-suppliers and sub-contractors as well as their costs and prices, decides.

The neoclassical approach to the size of the enterprise is related to the analysis of the long-term technological optimum of the branch, 
which results from the long-term curve of average costs and marginal costs. At their intersection, long-term average costs are the smallest and determine the limits of concentration, and thus the size of the enterprise. This analysis is an analysis of economies of scale. By increasing the concentration and scale of production, average costs after a period of decline and temporary stabilization increase again. The technological optimum of the sector, determining the optimal production scale, determines for example the scale of $20 \%$ of the share in sector production, which prefers the space for around five oligopolistic producers.

In the Coase approach, the analysis focuses not so much on average costs, i.e. the technological optimum, but on the comparison of the costs of activities in the enterprise with transaction costs of similar activities for contractors on the market of sub-suppliers and subcontractors. It does not focus on the effect of the scale of one company and its impact on the level of average costs, but on a comparative analysis of the company's costs with the costs of other enterprises and it is not about a single sector enterprise but the enterprises from many sectors. Without the precision of concepts and tools of cost analysis it is impossible to answer the basic question: to develop a given activity inside the company or contract it on the market? It is not only about clarifying the transaction cost account, but also about improving the operating cost accounting in the company. This requires a departure from the traditional generic cost account of the whole entity to a modern precise analysis of the costs of individual activities (costs of operations). Then the company's boss has strong arguments for discussions with company's individual departments and units because he can compare the costs of outsourcing in the field of activities of a given organizational unit with its costs. Then he can prove the lack of a sense to maintain it or impose a task to rebuild it. At present, when there is a progressive tendency to decrease the transaction costs of the global market in relation to analogous activities within the enterprise, a significant change in the size and, above all, in the nature of the enterprise must take place. The organizational and ownership nature of the enterprise is changing. The concentration and size of a company are becoming increasingly important. Enterprises can, for example, control and sell an increasing production volume, although as a result of using a large number of subcontractors and subcontractors, their direct contribution to employing contractors can be very small. 


\section{Influence of transaction costs on enterprises' ability to take on modern challenges}

The natural requirement of the company's operation is to adapt to the market situation. It is just that currently it is a different market flexibly accounting for sudden, irregular changes, hence the turbulent and open market. In business, turbulence is understood as rapid internal and external changes that force radical reactions.

The modern enterprise operates in an environment that Andrzej Koźmiński will describe as "generalized uncertainty" (Koźmiński, 2004, p. 27). Currently and in the foreseeable future, the new normality of the economy is that it no longer consists of cycles that can be forecast on a macro scale. Currently, one has to expect fluctuations and painful shocks that cause a significant increase in risk and uncertainty (Kotler \& Caslione, 2009, p. 32).

Instability is a derivative of freedom in the flow of capital across borders. Simultaneous restrictions of work flow intensify capital flows, which in this situation is becoming more volatile and sensitive to change. The effect of this is growing instability and uncertainty. The company faces non-evolutionary, violent and unpredictable, changes. The asymmetry between the market reaction, flexibly taking into account changes, and the delayed and inadequate reaction of enterprises is revealed (Foster \& Kaplan, 2003, p. 33).

An enterprise must learn to function at a time when it is inefficient to extrapolate past experiences to today and the future, because experiences are fast-aging and conditions are changing. And at the same time, the method of anticipation the future is ineffective because it is difficult to predict a growing number of unexpected changes in the world. In this situation, enterprises face the requirement to trigger flexibility and the ability to change. In a situation of rapid aging of experience, products, information, previously prepared strategies, the requirement to trigger flexibility becomes an absolute requirement.

At the same time, the company is facing an increasingly open global market. The globalization process, creating market activities across borders, before the conditions are compensated in the long-term, is at the initial stage of disclosing differences in prices, wages, costs, rates, taxes. The global market shows a huge number of diversified potential subcontractors and subcontractors with various qualities. 
Companies are challenged to take advantage of this opportunity and expand the selection field to the variants offered by the global market. Most enterprises are too conservative, accustomed to old rules and conditions. Consequently, they do not think in terms of the logic of the global market and thus do not take advantage of the opportunities that this market creates. It can be said that such enterprises give false information to the economic account and, above all, the alternative cost account. Disregarding the opportunities offered by the global market means artificial lowering of alternative costs and, consequently, demonstrating an apparent economic profit. Economic profit occurs when accounting profit outweighs the alternative costs, that is the best alternative effects from the use of the company's resources.

The great challenge facing businesses today is the creation of procedures that enforce the assessment of alternative costs from the global market perspective, i.e. the best use of what it offers. Using the analysis of transaction costs in the Ronald Coase formula is after all nothing more than a procedure leading to the use of opportunities offered by the global market. It offers many such products and production services that are cheaper than the costs that would be incurred by the company by carrying out similar activities using its own resources.

Earlier, I emphasized the importance of the flexibility and ability of enterprises to change in the current conditions. It can be said that a company in modern conditions must be flexible to survive, and very flexible to win. Globalization determines at the same time that the requirement is, increasingly, the introduction of creative destruction at the pace and scale of international markets. It can therefore be said that the globalization process leads gradually, as a result of information progress and the development of global market relations, to the decline in the role and duration of environmental, local and national innovation, and the growing role of leading global innovations (Frank \& Cook, 1995). The time of globalization is not only a great pressure on innovation, but also on imitations. In this situation, not only innovation, but also the requirement of imitation, enforces the ability to destroy the old one. The one who cannot destroy the old will himself be destroyed.

High fixed costs and costs of destroying the old are undoubtedly the barriers to the flexibility of enterprises. Capital is very much involved 
in fixed assets, that is measures that are adapted to the old conditions and needs, large stocks of raw materials, resources and finished products, large employment of employees for an indefinite period, i.e. those who are paid not only for their work, but for being ready to work as well. In view of the requirement of increasing flexibility, the need to free the burden of fixed costs and the costs of destroying the old has become a great problem for enterprises. Fixed costs and costs of destroying the old are connected with maintaining resources regardless of how intensively these resources are used. In conditions of high variability of the business environment, the stability in the use of resources decreases, thus the share of unproductive fixed costs in enterprises that have a large stock of fixed assets and inventories grows.

Thus the problem how to get free from the burden of fixed costs and the costs of destroying the old arose. An effective way has become the commissioning of various types of activities and services to others, thus striving for the production to be dispersed, that is, to burden the production process with the resources of others, burdening the contractors with the costs of destroying the old at the same time. This process of outsourcing production has become beneficial not only because it reduces the cost of fixed costs and increases flexibility, but because it leads to a reduction in costs as a result of the use of lower transaction costs of the market. In this way, outsourcing became a way to accumulate benefits from the flexibility and due to the lower level of transaction costs of orders in relation to enterprise's own direct involvement of the company's resources for similar activities. Lower transaction costs, leading to depopulation, increase flexibility and the ability to change. On the other hand, the increase of flexibility, reducing the fixed costs burden contributes to the reduction of transaction costs in the perception of enterprises and increase in the profitability of orders.

The company, which increasingly outsources certain activities to subcontractors, transfers fixed costs related to maintaining some fixed assets and pays only for their use.

Moving away from basing the production process on own means of production is a revolutionary change in the priorities and ways of functioning of enterprises. This opens the way to qualitative organizational and strategic changes of enterprises. There is a departure in the production process from own fixed assets, own resources of 
semi-finished and finished products towards the activity based increasingly on subcontractors and sub-suppliers operating in the system exactly on time. Therefore, it is becoming more difficult to move away from the outsourcing of production based on own branches located in various places on the global market, to outsourcing based on contracts with formally independent sub-suppliers.

On the modern market, the most flexible are the companies that focus on contractual outsourcing, that is a specific bundle of contracts with formally independent sub-contractors and sub-suppliers. This differs from capital outsourcing, in which the enterprise transfers part of the business with human potential and creates a new legal entity, new branches within one capital and one ownership.

Truly outsourcing happens in contractual outsourcing. Then we have orders that correspond to the logic of using lower market transaction costs by the enterprises and the coordinators of the network of independent subcontractors and sub-suppliers will free themselves from the limitations of one owner of the means of production fully responsible for their use. This has a fundamental impact on the company's strategy. In general, care is taken to use their production capacities. In this situation, it does not have to make its supply chain to the consumer market dependent on the requirements of the factory and its production capacity but on the requirements of the customers. From the point of view of the company, it is a fundamental improvement of the conditions of adjustment to the market, and thus a significant increase in its flexibility takes place. Lower transaction costs, which support an increase in orders independent of sub-contractors and sub-suppliers, allow limiting the production process based on own production means, which increases flexibility and in a derivative way affects an additional reduction in transaction costs.

Nowadays, insufficient flexibility of enterprises results also from the difficulty of getting off the beaten trail, from the need to reject solutions that cannot cope with the new situation. Joseph Schumpeter has repeatedly emphasized that the real problem is not only how the new is created, but also how the old can be destroyed. John Keynes also drew attention to this, saying that the real problem of enterprises is not in new ideas, but in the ability to escape from the old ones (Foster \& Kaplan, 2003, p. 145). When the coordinator of the network bases a serious scope of the production process on the subcontractors production means, then technological and organizational changes force 
the costs of destroying the old on the subcontractors. The network coordinator's role remains in motivating changes and, consequently, destroying the old manufacturing apparatus. The strength of imposing changes at the orderer is high, as contractors, subcontractors and sub-suppliers in the modern market are easily substitutable. The competition for orders is high on the modern market.

To adapt to changes and innovations one needs to be able to maneuver and have large financial reserves for research. This requires high turnovers and high margins. Order coordinators are, by rule, entities that perform high rates of return on their own capital. By often giving up their own means of production and direct participation in it, they can focus more on financing research and implementation. An important derivative of the process of using the decrease in transaction costs and profitability of orders is the simultaneous, not so rare, possibility of using innovative competencies of sub-suppliers. Too often, the relationship between the size of entities and the scale is simplified. A large enterprise is associated with a large scale, and small with a small scale. In practice, it is essential to order specific, often small services or production of individual components. In such a situation, a small entity may have a much larger scale in relation to the cell of a large partner producing an element for its own needs. A small enterprise may specialize in the production of a given small element for many recipients. In such a situation, it may have not only a large scale of a given production, high efficiency, but also extensive experience and profitability of innovations in a given area.

A good example of how one can use the innovation competences of others is the history of Finnish Nokia. At the beginning of the 1990 s, a failing company that previously produced rubber footwear changed management. The new management was able to accurately identify the problem, i.e. what can be sold on a large scale. The easiest thing to do is to look at gaps in innovation, something that innovation has overlooked or did not consider important. Nokia saw such a gap in the field of personal cell phones. Everything, and hence the projects and sub-assemblies, was outsourced to sub-suppliers and sub-contractors. Nokia showed how one can use the technological competence of the sub-suppliers, without possessing the resources itself. It made a company that changed the country, in a sense, almost out of nothing. 


\section{Transaction costs vs. the distance between a traditional company and an "empty company"}

In recent decades, the growing requirement of flexibility and change in transaction costs, increasing the profitability of the outsourcing process has led to fundamental transformations of enterprises. The most far-reaching effect of these transformations is the so-called "empty company", that is the company that develops the order system so that it does not employ any executive employees, but only deals with organizational and coordination functions. The traditional enterprise model is a model that was created (and possibly lasts) at a time when it was considered that the transaction costs of orders are higher than the costs of analogous activities in the enterprise. Then, the concentration of the enterprise is paying off, because according to Ronaldo Coase, in such a situation, we reduce costs by shifting the activities from the market to the enterprise.

The traditional company is what Peter Drucker described in the 1940s when presenting the management of General Motors. It was a factory with 47 branches and thousands of production and service units with high spatial concentration (Beatty, 2004, pp. 57-75).

When writing about a traditional enterprise, I mean a large concentration of individual production phases in the factory, the dominance of its ownership of the means of production. In such a factory, the desire to adapt to the requirements of market changes is based on production capacity reserves, reserves of production means and finished products as well as employment of employees for an indefinite period, with a view to working for a lifetime. Such a company is at the same time based on a hierarchically shaped organization and adequate management system. Figuratively, it can be said that it is a factory with a wide roof, closed gates and a developed mentality of the warehouse keeper and the owner.

The traditional factory is characterized for various reasons by dysfunctionality to an increasingly complex, changing and turbulent environment. It is primarily inflexible, and therefore unadapted to the era of discontinuities, and therefore violent, non-evolutionary and unpredictable changes. It is not adapted to the operation of the market across borders, nor is it able to use the IT revolution to explore the market and improve logistics. Such a company is not suited to a wide selection of places of purchase and places of sale. It is not focused on 
external suppliers and cooperators, so it does not have to examine transaction costs. Shutting up in the traditional area of activity it misses better variants offered by the global market. As a consequence, it is an ineffective entity from the point of view and logic of the global market.

Such company is inflexible, because it is burdened with fixed costs and its own means of production, it cannot use economic arbitration and great opportunities that open the market in access to the masses of sub-suppliers and subcontractors who are submissive because they are easily substitutable. Such enterprise is burdened not only with fixed costs, but nowadays with very high costs of destroying the old, which results from high pressure of innovation and imitation.

The old, traditional model of the company adapted to market changes based on reserves held by the company, a large range of inventories, ready-made components and products and employment reserves related to employment for an indefinite period (partly paid for work, when it is not available at the moment). Previously, the low degree of volatility, evolutionary transformations and high predictability meant that such adjustment to the market was possible. With the current dynamics of change, the traditional enterprise model is in danger of falling into fixed costs.

If the model of a traditional enterprise is so unsuited to contemporary challenges, then the adapted model must contain opposite features. So, again, figuratively speaking, it should be a company with an increasingly smaller roof, gates open to cooperate, lack of mentality of the warehouseman, because stocks of finished products and products will be replaced with perfect logistics of cooperation with sub-suppliers and subcontractors with delivery on time. The company has to replace the market adjustment with reserves for management and organization change, which change the process of adapting production to the needs of customers, and not the need to use its own means of production, because there are fewer in the company. The means of production are located in the mass of proprietary subcontractors and subcontractors who are easily substitutable on the modern market. The mentality of the warehouse keeper and the owner is replaced by the mentality of the organizer, the coordinator and the orderer.

The "empty company", which corresponds to modern requirements, because it is consistently going towards scrupulously analyzing transaction costs, which can be considered the most professional use of alternative costs in the economic calculation, goes the furthest in 
this direction. It is best to call this type of company "smart companies". Such companies can nowadays realize a large economic surplus without a large own capital contribution and without production competence. Capital and production competences are with the contractors.

The company acting as the orderer and coordinator is not the owner of the means of production, but it also has the function of leadership and control in a different form. Leadership is based on mutual interest, partnership and conscious cooperation. The coordinator is increasingly called the network orchestrator, because for a large group of contractors, he is like a conductor who is invited to conduct them like an orchestra (Hagel \& Seely, 2005).

An example of an empty company that is not the owner of any factory that has been described in the book (Fung \& Wind, 2008) is Li $\&$ Fung. A few years ago, it coordinated the network of 8,300 suppliers serviced by 70 coordination offices located in more than 40 countries. The company indirectly provided employment for 2 million people in the network of sub-suppliers, but it did not employ any production worker on its own. It provided the market with branded clothing and other consumer goods for the sum of 8 billion USD. The profitability of its assets exceeded $38 \%$.

Such company not only draws its strength from the information advantage which determines its ability to obtain demand and shape orders for sub-suppliers, and thus from its own competences, but also draws on the ability to recognize and acquire competences that are found in the network of sub-suppliers and subcontractors. This type of company operates with a minimum internal organization, based on excellent IT infrastructure and highly qualified staff, it can realize large orders, developing the image of a trustworthy company. Guarantees and reliability of such a company are a result of maintaining a large network and coordinating subcontracting connections. A much larger network than the need to carry out specific orders of the global market, ensures timely implementation and shapes the company's opinions as reliable.

\section{Polarization of enterprises}

The requirement of flexibility and taking changes in transaction costs into account requires that the subcontractors and sub-suppliers be outsourced and searched for. Those companies that adapt to the 
above challenges, i.e. orderers, coordinators, so-called orchestrators, win, but the question arises; what about the rest, large numbers of sub-suppliers, contractors? We are increasingly dealing with the transformation of a traditional enterprise into an orderer coordinating contractual outsourcing, a bundle of contracts. The orderer coordinator is undoubtedly the winner of these processes. But contractors, subcontractors, sub-suppliers who must seriously submit to the orderer do not belong to the winners of the process, although they are forced to approve it.

Sub-suppliers, sub-contractors are usually subordinated entities, because they are easy to be replaced. On the sub-suppliers' market, there is an unsatisfied queue waiting for the order... As a consequence, contractors are characterized by low price elasticity of supply, and thus a small bargaining power. They accept imposed subcontracting conditions that are difficult to them with resignation and submission. Globalization has enabled and facilitated the transfer of subcontracting activities to less demanding and cheaper markets, which increased competition and requirements for sub-suppliers from developed countries.

Orderers, network coordinators controlling contracts and trying to win monopsonistic power related to such manipulation of demand (not supply, as monopoly) to realize the benefit from low sub-supplying and subcontracting prices. In this situation, monopsonistic power is not determined by the classic arrangement of the entity with one buyer, but with the intensity of sub-supplying and subcontracting competition and the market of easily replaceable contractors. Each major orderer coordinator can therefore actively influence the price of the orders. The advantage of the orderer using lower transaction costs is another additional path to their reduction and the way to profitability of orders.

Thus, the real sphere of the economy in the contemporary world is clearly divided into those who commission and those who are commissioned. Between those who commission and those who are commissioned, there is a growing distance in the strength and benefits of business. Those who are commissioned by subordinating to stronger market players lose the ability of active competition. This concept was introduced by the Italian economist Vilfredo Pareto. Active competition is the possibility for economic operators to influence the price and preferences of buyers, while in the case of passive competition, entities 
do not have this option. Sub-suppliers lose more and more influence on the price, and at the same time must comply with the client's requirements in terms of technical and technological requirements.

\section{CONCLUSIONS}

The above remarks can be transferred to the level of the country's economy. In the long process, the country, the majority of which remains in the sphere of subcontractors of global corporations that use economic arbitrage and analysis of transaction costs to impose difficult conditions on the subcontractors, loses. Poland is unfortunately in this group of countries in which domestic enterprises operate mainly in the sub-supplying and subcontracting spheres. In order for Poland to reach a group of orderers in a wider scope, it must change the nature of competition and make a much wider and better use of intellectual capital.

For several years, I have been proposing treating "smart companies" as public innovation, because in my opinion, waiting only for their spontaneous, bottom-up development is a great waste and a great untapped opportunity (Szymański, 2011, pp. 266-271). I believe that massive support for their creation would be a strong catalyst for the entire economy, making us pioneers both in pursuit of the opportunities that flow from the global economy and those who can stimulate what the most difficult in the modern economy, namely a significant increase in the flexibility of enterprises. The form of public innovation should be state initiation and comprehensive support for the creation of incubators of "smart companies". Without thinking in terms of the logic of the global market and the needs of flexibility, we are condemned to traditional and defensive solutions.

\section{REFERENCES}

Beatty, J. (2004). Świat wedtug Petera F. Druckera. Tłum. D. Bakalarz. Warszawa: Studio Emka.

Coase, R.H. (1937). The nature of the firm. Economica, 4(16), 386-405.

Foster, R. \& Kaplan, S. (2003). Twórcza destrukcja. Tłum. M. Nycz, J. Jakubczyc \& M. Mach. Łódź: Galaktyka. 
Frank, R. \& Cook, P. (1995). The Winner-Take-All Society. New York: Free Press.

Fung, W.K. \& Wind, Y. (2008). Konkurencja w płaskim świecie. Przedsiębiorczość i zarzadzanie. Tłum. A. Ehrlich. Warszawa: Akademia Leona Koźmińskiego.

Hagel, J. \& Seely, J. (2005). The Only Sustainable Edge: Why Business Strategy Depends on Productive Friction and Dynamic Specialization. Boston: Harvard Business School Press.

Kotler, P. \& Caslione, J.A. (2009). Chaos - zarzadzanie i marketing w erze turbulencji. Tłum. D. Bakalarz. Warszawa: MT Biznes.

Koźmiński, A.K. (2004). Zarzadzanie w warunkach niepewności. Warszawa: WN PWN. Szymański, W. (2011). Niepewność i niestabilność gospodarcza. Warszawa: Difin. Williamson, O.E. (1998). Ekonomiczne instytucje kapitalizmu. Firmy, rynki, relacje kontraktowe. Tłum. J. Kropiwnicki. Warszawa: PWE. 